\title{
Introduction: Economic Performance
}

ABSTRACT. This paper introduces the special issue of Small business Economics on Performance. The concept of economic performance refers to the degree to which society's resources are being used as efficiently as possible. Where the field of industrial organization has emphasized the influence of market concentration on economic performance, the papers of this special issue zoom in on the link between firm size and economic perfornance.

The field of industrial organization became integral to the study of economics because it provided a lens through which to view and analyze economic performance. This framework posited that the structure of an industry would influence the conduct of firms in that industry, which in turn would ultimately shape the economic performance of those firms and ultimately the industry (Audretsch and Yamawaki, 1991; Scherer and Ross, 1990). But what actually is meant by economic performance and what is the yardstick used to measure it?

Considered most generally, the concept of economic performance refers to the degree to which society's resources are being used as efficiently as possible to maximize the welfare of the individuals within that society. It is generally considered to have a least five dimensions, spanning the efficient use of inputs, the most effective organization of production, prices reflecting marginal cost and equal to long-run average cost, economic profits which are zero in the long run, a maximum degree of technological

Final version accepted on August 18, 1995

Centre for Advanced Small Business Economics,

Erasmus University Rotterdam,

Rotterdam, the Netherlands

and

EIM Small Business Research and Consultancy progress, and the generation of enough jobs to employ the workforce at high paying and high quality activities.

The literature in the field of industrial organization has traditionally addressed the issue of economic performance with a particular emphasis of the impact of market concentration on the various elements comprising economic performance listed above. Why is there this emphasis on the high end of the size distributon? What about its low end? That is, what about the link between firm size, and in particular, small business and economic performance? Here industrial organization research has had little to say. In particular, other than a handful of studies (Aiginger and Tichy, 1991; Prince and Thurik, 1993; Schneider and Lenzelbauer, 1993; and Schneider, 1991), surprisingly little is known about the relationships between firm size, productivity and profitability.

To fill this void left by the industrial organization literature The Tinbergen Institute in Rotterdam sponsered The Third Global Conference on Small Business Economics on August 26-27, 1995. The Tinbergen Institute is the Netherlands Reseach Institute and Graduate School for General and Business Economics. The Tinbergen Institute was founded by the Faculties of Economics and Econometrics of the Erasmus University in Rotterdam, the University of Amsterdam and the Free University in Amsterdam.

This special issue of Small Business Economics is devoted towards a carefully selected and edited group of papers from the Tinbergen Conference. They focus on the links between economic performance and small business. The aspect of economic performance most directly focusing on the role of small business has been, perhaps surprisingly, technological change. We felt that this issue is sufficiently important to merit inclusion in a Special Issue by itself, which was published 
in Volume 8, Number 5 of Small Business Economics.

In "The Comparative Organisation of Large and Small Firms: An Information Cost Approach", Mark Casson introduces a new theory applying the concept of information cost to the organization of the firm. His aim is to explain why firms in some industries are small while they are large in others. His approach supplements that of the transaction costs theory. Christophe Boone and Arjen van Witteloostuijn provide a model and empirical results suggesting that both objective and subjective human capital have substantial impacts upon the performance of firms in "Industry Competition and Firm Human Capital". This follows from their approach to insert some elements of sociological theory and organization ecology in the more orthodox stucture-conduct-performance paradigm. In "Confronting the Implications of the Cournot Model with Industry and Firm Data", Karl Aiginger provides an empirical test of the relationship between pricing and firm size. His research fits also into the stucture-conductperformance paradigm. John Hudson analyzes the impact of bankruptcies on unemployment in "Bankrupticies, Firm Size and Unemployment: A Big Bang Theory of Economic Cycles". The link between firm size and employment is also the subject of "Firm Size and Employment Determination in Dutch Manufacturing Industries" by Marcel Lever. One of his conclusions is that employment adjustment is faster in small firms than in large ones. In "Commitment Lending Under Asymmetric Information: Theory and Tests on U.K. Startup Data", Robert Cressy uses data on new business startups to examine the role of contract parameters in solving the bank's problem of lending under asymmetric information. Finally, the links between firm size and job generation are examined by Geoffrey Robson in "Unravelling the Facts about Job Generation". Starting with the work of David Birch (1979) and spanning the nearly two decades untill that of Davis et al. (1996), research on the relationship between firm size and job generation has been hotly contested by both scholars and policy makers. Robson provides a new perspective on the debate by arguing that the previous work has overlooked a number of key economic concepts such as the nature of the firm, the nature of jobs and how these two interact.

\section{References}

Aiginger, K. and G. Tichy, 1991, 'Small Firms and Merger Mania', Small Business Economics 3(2), 83-101.

Audretsch, David B. and Hideki Yamawaki (eds.), 1991, Structure, Conduct and Performance: Leonard Weiss, New York: New York University Press.

Birch, David L., 1979, 'The Job Generation Process', MIT Program on Neighbourhood and Regional Change, Cambridge, Mass.

Davis S., J. Haltiwanger and S. Schuh, 1996, 'Small Business and Job Generation: Dissecting the Myths and Reassessing the Facts', Small Business Economics 8 (forthcoming).

Prince, Y. M. and Roy A. Thurik, 1993, 'Firm-Size Determination and Price-Cost Margins in Dutch Manufacturing', Small Business Economics 5(3), 173-186.

Scherer, F. M. and David Ross, 1990, Industrial Markes Structure and Economic Performance, Boston: Houghton Mifflin

Schneider, Friedrich, 1991, 'Efficiency and Profitability: An Inverse Relationship According to the Size of Austrian Firms', Small Business Economics 3(4), 287-296.

Schneider, Friedrich and Werner Lenzelbauer, 1993, 'An Inverse Relationship between Efficiency and Profitability According to Size of Austrian Firms: Some Further Results', Small Business Economics 5(1), 1-22. 